\title{
The State Fact of the Rural Area of the Kurdistan Regional Government
}

\author{
Rezhen $\operatorname{HARUN}^{\left.1^{*}\right)}$, Iulia MUREȘAN²*), Felix ARION ${ }^{2)}$, Diana DUMITRAȘ²) \\ 1) Department of Agricultural Extension. University of Sulaimani, Kurdistan Regional Government-Iraq. \\ 2) Department of Economic Sciences. University of Agricultural Sciences and Veterinary Medicine Cluj- \\ Napoca, Romania. \\ ${ }^{*}$ Corresponding author, e-mails: rezhen.rashid@univsul.edu.iq; iulia.muresan@usamvcluj.ro;
}

BulletinUASVM Horticulture 72(1) / 2015

Print ISSN 1843-5254, Electronic ISSN 1843-5394

DOI:10.15835/buasvmcn-hort:10506

\begin{abstract}
The rural area of Kurdistan region has specific characteristics and faces many challenges. The rural space of Kurdistan is affected by poverty, and the farmers are dealing with many problems and they hardly survive. The Kurdistan Region is located SW of Asia and NE of Iraq and is composed of three governorates: Erbil (Hawler), Suleimani, and Duhok, located within the northern part of the Federal Republic of Iraq (Iraqi Constitution, Article 62). The aim of the paper is to analyze the current situation of the rural region of KRG (Kurdistan Region Government) in order to propose new solution for sustainable development of the area. For the purpose of the paper a survey was conducted during June-September 2012. The collected data were analyzed for each of the three governorates, and for each of the precipitation zones (A zone and B zone). The results of the field research show that the rural population of Kurdistan has an average age less than 26 years old. And at the same time is highly suffering from a lack of education which is higher in the case of older people. More than a quarter (28.45\%) is illiterate, while almost $30 \%$ graduated only the primary school, meaning that they having the basic knowledge of reading and writing. The number of people not educated in zone B is one quarter higher than in zone A. The results of the survey revealed the necessity for improving the specific conditions for sustainable development in the research area.
\end{abstract}

Key words: rural area, socio demographic, education, farmer

\section{INTRODUCTION}

There is a few literature on the issue of rural area of the Kurdistan region, in general, and on the condition of the socio- demographic, education in particular. For this, take some facts from another countries and territories where had the same issues as we have in the study case, as well, by supporting the survey questioner for our case- study for the rural area of the Kurdistan region. The development as a term in rural area involves improvement in the pattern of life (Acharya, 2008). If there is any absence of each of basic necessities of life, freedom and self-respect, or limited in supply, it means absolute underdevelopment (Singh, 2009). In the modern society, the managing and developing of the rural area is one of the most progressing matters to equate between the conservation needs and the modernizing trend (Barbu and Capusneanu, 2012).
Also, this challenge obverse the rural areas in all around the world is in general the same, many questions are facing to governments to how to catalyze the rural economy so as to increase economic growth, retain populations and create sustainable living conditions (Organization for Economic Co-Operation and Development(OECD), 2008). The rural area of Kurdistan region has specific characteristics and faces many challenges. The rural space of Kurdistan is affected by poverty, and the farmers are dealing with many problems and they hardly survive (MoP, 2011). The aim of the study was to analyze the socio-demographic characteristics of the rural area of the KRG, especially of the farmers, since these play an important role in agricultural development. 


\section{MATERIALS AND METHODS}

The research was conducted in Kurdistan Region of Iraq. Kurdistan Regional Government (KRG) is located within the North-East part of Federal Republic (Iraqi constitution, article62). The region is divided into three governorates: Erbil, Sulaimani and Duhok. The research region lies between latitudes $34^{\circ} 42^{\prime} \mathrm{N}$ and $37^{\circ} 22^{\prime} \mathrm{N}$ and between longitudes $42^{\circ} 25^{\prime} \mathrm{E}$ and $46^{\circ}$ $15^{\prime}$ E. The Kurdistan region mainly lengthens across the Zagross Mountain up to the Taurus Mountains in Turkey. The region shares it borders with Syria in the west, Turkey in the north and Iran in the east (Mizori, 2012). The area of the region is $42,812 \mathrm{Km} 2$ (MoP, 2012) without the disputed area as Kirkuk, Shangar and Khanaqin, the total area is around 73,618 km2 (Talib, 2005), and represents $17 \%$ of the total area of Iraq. To achieve the purpose of this paper during June and September 2012, 236 questionnaires were applied to the farmers from 46 villages. The questionnaire was divided into three parts: the first part contained questions about the socio-demographic profile of the farmers and characteristics of the farms, the second part included question about the irrigation water, and the third part included questionnaire included the valuation questions about the willingness to pay for water in agriculture. To achieve the aim of the paper the data about the socio-demographic profile of the famers were analyzed.

To establish the size of the sample the simple random sample, without replacement, continuous variable, with a relative error of $2.5 \%$, and $95 \%$ confidence interval was used. Based on the average rainfall the research area can be divided into two zones: secured rain-fed line (more than 600mm.yr-1), Sangassar Zone (A zone), and semi and unsecured rainfed line (less than 600mm.yr-1), Kirkuk zone (B Zone) (Mohammad Ali, 2008) The size of the sample was establish by using the simple random sample, without replacement, continuous variable (age), with a relative error of $2.5 \%$, and $95 \%$ confidence interval (Merce et al., 2011).

Based on the average rainfall the research area can be divided into two zones: secured rain-fed line (more than 600mm.yr-1), Sangassar Zone (A zone), and semi and unsecured rain-fed line (less than 600mm.yr-1), Kirkuk zone (B Zone) (Mohammad Ali, 2008) The data were analyzed for each governorate and for each of the precipitation areas. The data were analyzed using the descriptive statistics. The link between different variables was tested using chi-square test.

\section{RESULTS AND DISCUSSIONS}

In the rural area of the Kurdistan region, the distribution of the population by gender is balanced. The ratio of males in the total population represents $50.82 \%$. The results are very close according to the national level (Iraq Household Socio Economic Survey (IHSES), 2012). Results of the survey shown that, villagers are living in rural area young, illiterates with an average age around 26 years (Tab. 1, Fig. 2). Around $45 \%$ of them are from the rural area around (15-29) years old, almost $70 \%$ are under 30 years old.

Compared with the data registered in Romania in 2010, regarding the distribution of the rural population by age group, it was observed that in the rural area of Kurdistan Regional Government people are younger.

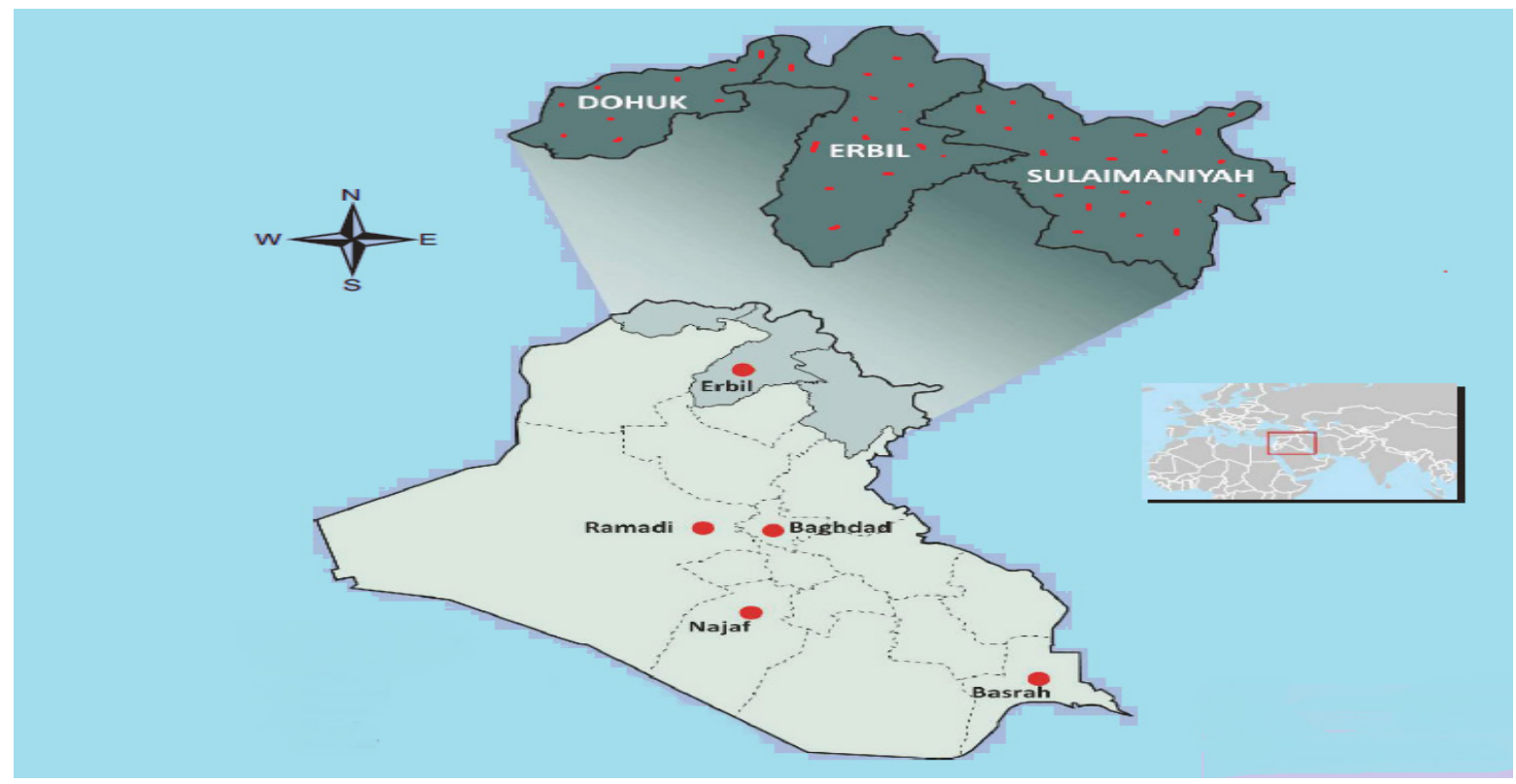

Fig. 1 Location of studied area, Kurdistan regional government (KRG-Iraq); MOAWR, 2010 
While in Kurdistan region $25 \%$ of the rural population have between 0-14 years old, in the rural space of Romania this category of age represents around $17 \%$. The percentage of persons younger than 30 years in the rural area of Kurdistan is around 70\%, almost double the percentage of people below 30 years old from Romanian rural space, which represents $37.13 \%$ (Pocol, 2013).

Tab. 1. Distribution of the rural population by gender and age (years) classes

\begin{tabular}{|c|c|c|c|c|c|c|c|c|c|c|c|c|c|}
\hline \multirow{5}{*}{$\begin{array}{l}\text { Region } \\
\qquad \frac{y}{0} \\
\frac{1}{3} \\
0\end{array}$} & & \multicolumn{2}{|c|}{$0-14$} & \multicolumn{2}{|c|}{$15-29$} & \multicolumn{2}{|c|}{$30-44$} & \multicolumn{2}{|c|}{$45-59$} & \multicolumn{2}{|c|}{$60-74$} & \multicolumn{2}{|c|}{$75-89$} \\
\hline & & No. & $\%$ & No. & $\%$ & No. & $\%$ & No. & $\%$ & No. & $\%$ & No. & $\%$ \\
\hline & Male & 38 & 42.70 & 72 & 50.35 & 15 & 32.61 & 22 & 64.71 & 7 & 70.00 & 1 & 100.00 \\
\hline & Female & 51 & 57.30 & 71 & 49.65 & 31 & 67.39 & 12 & 35.29 & 3 & 30.00 & 0 & 0.00 \\
\hline & Total & 89 & 27.55 & 143 & 44.27 & 46 & 14.24 & 34 & 10.53 & 10 & 3.10 & 1 & 0.31 \\
\hline \multirow{3}{*}{ 胥 } & Male & 47 & 47.96 & 92 & 55.42 & 17 & 28.33 & 31 & 59.62 & 10 & 66.67 & 0 & 0.00 \\
\hline & Female & 51 & 52.04 & 74 & 44.58 & 43 & 71.67 & 21 & 40.38 & 5 & 33.33 & 1 & 100.00 \\
\hline & Total & 98 & 25.00 & 166 & 42.35 & 60 & 15.31 & 52 & 13.27 & 15 & 3.83 & 1 & 0.26 \\
\hline \multirow{3}{*}{$\begin{array}{l}\vec{\Xi} \\
\tilde{\Xi} \\
\vec{\Xi} \\
\tilde{\Xi}\end{array}$} & Male & 114 & 52.29 & 237 & 55.37 & 48 & 33.10 & 55 & 51.40 & 29 & 85.29 & 2 & 100.00 \\
\hline & Female & 104 & 47.71 & 191 & 44.63 & 97 & 66.90 & 52 & 48.60 & 5 & 14.71 & 0 & 0.00 \\
\hline & Total & 218 & 23.34 & 428 & 45.82 & 145 & 15.52 & 107 & 11.46 & 34 & 3.64 & 2 & 0.21 \\
\hline \multirow{3}{*}{ 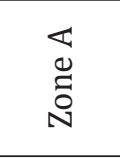 } & Male & 97 & 52.72 & 183 & 57.01 & 49 & 38.58 & 50 & 49.50 & 24 & 70.59 & 4 & 80.00 \\
\hline & Female & 87 & 47.28 & 138 & 42.99 & 78 & 61.42 & 51 & 50.50 & 10 & 29.41 & 1 & 20.00 \\
\hline & Total & 184 & 23.83 & 321 & 41.58 & 127 & 16.45 & 101 & 13.08 & 34 & 4.40 & 5 & 0.65 \\
\hline \multirow{3}{*}{$\begin{array}{l}ص \\
0 \\
0 \\
N\end{array}$} & Male & 102 & 46.15 & 218 & 52.40 & 31 & 25.00 & 58 & 63.04 & 22 & 88.00 & 1 & 100.00 \\
\hline & Female & 119 & 53.85 & 198 & 47.60 & 93 & 75.00 & 34 & 36.96 & 3 & 12.00 & 0 & 0.00 \\
\hline & Total & 221 & 25.14 & 416 & 47.33 & 124 & 14.11 & 92 & 10.47 & 25 & 2.84 & 1 & 0.11 \\
\hline \multirow{3}{*}{ 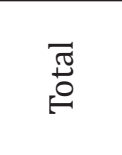 } & Male & 199 & 49.14 & 401 & 54.41 & 80 & 31.87 & 108 & 55.96 & 46 & 77.97 & 5 & 83.33 \\
\hline & Female & 206 & 50.86 & 336 & 45.59 & 171 & 68.13 & 85 & 44.04 & 13 & 22.03 & 1 & 16.67 \\
\hline & Total & 405 & 24.53 & 737 & 44.64 & 251 & 15.20 & 193 & 11.69 & 59 & 3.57 & 6 & 0.36 \\
\hline
\end{tabular}

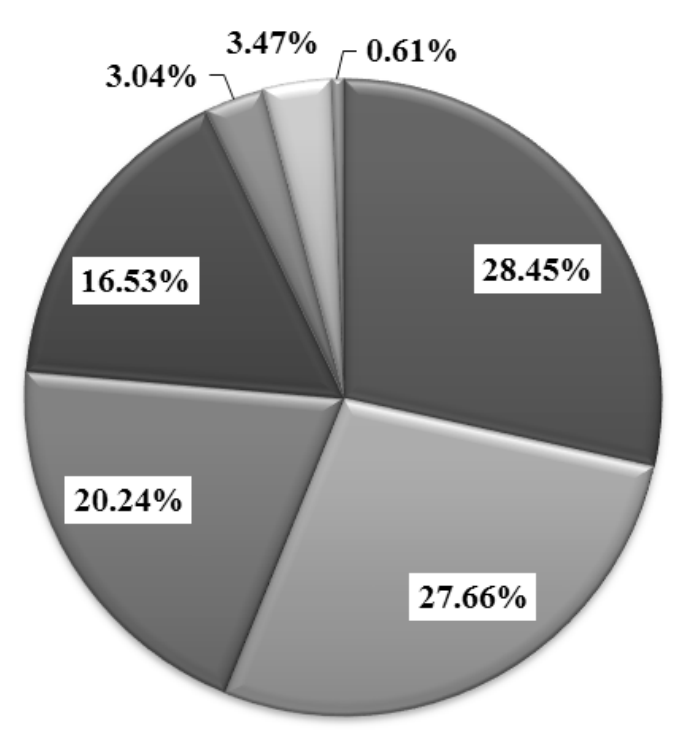

Enon educate

๑primary school

घecondary school

घpreparatory school

ⓘnstitutions

$\square$ university

$\square$ post university, training course

Fig. 2. Distribution of rural population by education level 
The analysis for the average age of the rural population shows that people from Duhok governorate are the youngest among the Erbil and Suleimani, with an average age of 24 years and 9 months, but the oldest one's are in Erbil governorate with an average age of 26 years and 5 months. From the precipitation distribution of the rural space observed that villagers from zone $\mathrm{A}$ are older than those from zone B by average with 2.4 years.

According to the results of the survey the rural community of the Kurdistan region is suffering from lack of education. Around (28.45\%) are uneducated (illiterate), and $27.66 \%$ ) graduated just the primary school, means that, they have the basic knowledge of reading and writing.

In the rural area, the ratio of illiterate rose with the increase of the age. The number of illiterate people between 30 and 44 years, which is by five times higher than the numbers of those are between 15 and 29 years. The situation is even worse in the case of the group age 45-59 years old, where almost three quarters are illiterates, the cause of the sorrowful facts regarding the injustice from former regimes and persecution against villagers in Kurdish rural area.

The number of dwelling villages having a higher education degree is quite low $3.47 \%$ by total, around $93 \%$ of them are between $15-29$ years old. The same trend can be observed also at the national level where only $3.6 \%$ of the population has a bachelor degree, and
$26.3 \%$ are illiterate and $17.5 \%$ just know how to read and write, but never graduated the primary school.

The development strategy of the Ministry of Planning (2012), regarding the education sector is mentioning these bad aspects of education and plan to improve teacher quality which is considerate to be the major gap of the education system in rural area of the Kurdistan region, to improve effectiveness of new curricula, to build new schools etc. so people can participate and take advantage of the education system. Compared with the rest (middle and south) of Iraq where around 85\%, Jordan (91\%) and Lebanon (92\%) of their children which under 9 years old are enrolled in school, but in the Kurdistan region, around 94.3\% are going to school (MoP, 2012). People who are living in rural space of the Kurdistan region, based on the collected data from the survey, $49.30 \%$ of them are considerate to be labor force (in the farm or other sectors), and the average age of the labor force from rural area is 37.8 years.

Also, the demographic characteristics of the head household were analyzed. The average age of the head of household is around 50.25 years, with small differences from each governorate to another (Tab. 2). This can be explained by the large number of family members (seven members by average).

The data from Tab. 3 shown that, over $53 \%$ of the head of household from the rural area of the Kurdistan region is illiterate, with the highest percent in Duhok

Tab. 2. Age distribution of the first family member (years)

\begin{tabular}{cccccc}
\hline & $\begin{array}{c}\text { No. of } \\
\text { observations }\end{array}$ & Min & Max & Mean & Std. Deviation \\
\hline Duhok & 44 & 28 & 77 & 49.98 & 10.540 \\
\hline Erbil & 56 & 26 & 73 & 50.00 & 11.760 \\
\hline Suleimani & 136 & 26 & 86 & 50.47 & 11.353 \\
\hline Zone A & 118 & 26 & 86 & 50.44 & 12.352 \\
\hline Zone B & 118 & 26 & 73 & 50.09 & 10.052 \\
\hline Total & 236 & 26 & 86 & 50.27 & 11.238 \\
\hline
\end{tabular}

Tab. 3. Education level of the first family member (\%)

\begin{tabular}{ccccccc}
\hline & Non educated & $\begin{array}{c}\text { Primary } \\
\text { school }\end{array}$ & $\begin{array}{c}\text { Secondary } \\
\text { school }\end{array}$ & Preparatory & Other & N.A \\
\hline Duhok & 63.64 & 20.45 & 9.09 & 4.55 & 2.27 & 0.00 \\
\hline Erbil & 48.21 & 28.57 & 8.93 & 12.50 & 0.00 & 1.79 \\
\hline Suleimani & 52.21 & 31.62 & 9.56 & 5.88 & 0.74 & 0.00 \\
\hline Zone A & 40.68 & 35.59 & 11.86 & 10.17 & 1.69 & 0.00 \\
\hline Zone B & 66.10 & 22.03 & 6.78 & 4.24 & 0.00 & 0.85 \\
\hline Total & 53.39 & 28.81 & 9.32 & 7.20 & 0.85 & 0.42 \\
\hline
\end{tabular}


governorate (63.64\%) and the lowest in Erbil 48.21\%, which is mean the difference between Erbil and Duhok governorates are more than $15 \%$.

A significant difference can be observed between the two precipitations zone. The number of those who are not educated in zone B is one quarter higher than in zone A. The age does not seem to play any role in this situation, regardless that by general it was noticed that older people are less educated and the fact that people from zone B are younger than those from zone A.

To see if there is any link between the level of education and the age of the respondents the null hypothesis was assumed:

$\mathrm{H}_{0}$ : The education level is not related with the age of the respondents.

$\mathrm{H}_{\mathrm{a}}$ : The education level is related with the age of the respondents.

The Chi-Square test was applied in order to see if the null hypothesis is assumed or not.

The null hypothesis was not accepted, the $\chi_{\text {value }}^{2}$ (305.479) is higher than the theoretical $\chi_{0.05 ; 44}^{2}(60.5)$. The relation between respondents' education and age is significant at 0.05 level.

The Contingency Coefficient indicates that, the level of education of the respondents with main activity farming and their age is a high association (Tab. 5).

The Pearson's R correlation coefficient indicates a weak negative relationship between the two variables, which indicates that when the age of the people who have main activity agriculture increases, the level of education decreases.

\section{CONCLUSION}

The socio-demographic in the collected data were analyzed from three different points of view to obtain general information about the gender, age, education level's distribution, family in rural area of Kurdistan. Furthermore were analyzed the socio-demographic characteristics of the respondents whom declared their main activity farming, this was done to see a clear profile of the persons involved totally in the agricultural activity.

The results of the field research show that the rural population of the Kurdistan has an average age less than 26 years old. And at the same time is highly suffering from a lack of education which is higher in the case of older people. Around (28.45\%) is illiterate, while $(27.66 \%)$ graduated in the primary school, it means, they having the basic knowledge of reading and writing. The illiterate people in zone B, it is about quarter higher than in zone A.

The results of the study revealed the necessity for improving the specific conditions for sustainable development of the rural area. The events that occurred in KRG during the last decades of the last century (wars, Anfal genocide etc.) had direct impact on the depopulation of the rural are. It is considered necessary to convince the migrated farmers to return to their abandoned villages in order to conduct and develop agriculture activities. A possible solution is to assure them the access to new technology such as machines and cultural practice facilities, offering financial support, know-how, consultation and education, by subsidies.

Tab. 4. Chi-Square Tests

\begin{tabular}{cccc}
\hline & Value & Degree of freedom & P \\
\hline Pearson Chi-Square & $305.479^{\mathrm{a}}$ & 44 & .000 \\
Likelihood Ratio & 122.067 & 44 & .000 \\
Linear-by-Linear Association & 3.825 & 1 & .050 \\
No. of Valid Cases & 165 & & \\
a. 51 cells (85.0\%) have expected count less than 5. The minimum expected count is .02. \\
\hline
\end{tabular}

Tab. 5. Symmetric Measures

\begin{tabular}{lccccc}
\hline & Value & $\begin{array}{c}\text { Asymp. Std. } \\
\text { Error }^{\mathrm{a}}\end{array}$ & Approx. $\mathrm{T}^{\mathrm{b}}$ & $\mathrm{P}$ \\
\hline Nominal by Nominal & Contingency Coefficient & .806 & & & .000 \\
\hline Interval by Interval & Pearson's R & -.153 & .127 & -1.973 & $.050^{\mathrm{c}}$ \\
\hline No. of Valid Cases & 165 & & & \\
\hline \multicolumn{4}{l}{ a. Not assuming the null hypothesis. } \\
b. Using the asymptotic standard error assuming the null hypothesis. c. Based on normal approximation. \\
\hline
\end{tabular}


From the precipitation distribution of the rural space can be observed that people from rural zone $A$ are older than those from rural zone B by average with 2.4 years. The reason for this disparities between the two precipitation zones and the governorates, have already been mention above (wars, genocide etc.), especially in B zone of Suleimani and Erbil (Hawler).

\section{REFERENCES}

1. Acharaya BR (2008). Dimension of Rural Development in Nepal. Dhaulagiri Journal of Sociology and Anthropology. 2:181-192.

2. Barbu CM and Căpuşneanu S (2012). Agriculture, Environment and Sustainable Development of Rural Areas. International Journal of Academic Research in Business and Social Sciences. 2(9).

3. Iraq Household Socio Economic Survey (IHSES), (2011) Iraq Knowledge Network Survey, Printed by Press SCOIraq.

4. Merce E, Merce CC and Dumitras DE (2011). Prelucrari statistice caiet de protocol, Editura AcademicPres

5. Mizori, AS (2012). The Geopolitical Weight of waters of Kurdistan River's, (مف رانالا هايجل ىكيتيلوبوي
ناتسدروك (ن), page: 394, Spirez Press \& publisher, KurdistanDuhok (Arabic).

6. Ministry of Planning, (MoP), (2012) Regional Development Strategy for Kurdistan Region, KRG.

7. Mohamed-Ali JJ (2008). Water Resources and its Sustainability for Agricultural Development in Sulaimani Governorate. PhD Thesis, University of Suleimani.

8. Organization for Economic Co-Operation and Development (OECD), (2008). Towards Sustainable Agriculture. Contribution to the United Nations Commission on Sustainable Development 16. www.oecd.org/publishing/ corrigenda.

9. Pocol CB (2013). Economie rurala - Identitate si Actualitate, Editura AcademicPres

10. Singh K (2009). Rural Development Principles, Policies and Management. Third Edition. SAGE Publications India.

11. Talib JT (2005). Geopolitical foundations of national security in the Kurdistan region, (Arabic), (ناموقمل)

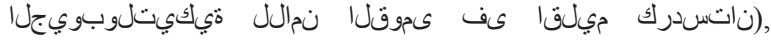
Kurdistan center for strategic researches, 580, 6/32/5, Sulaimani. 